\title{
Katherine S. Newman (ed): Laid Off, Laid Low: Political and Economic Consequences of Employment Insecurity
}

\author{
New York: Columbia University Press, 2008, 124 pp.
}

\section{Iryna Shevchuk}

Published online: 6 March 2010

(C) The Author(s) 2010. This article is published with open access at Springerlink.com

Job security is always an important topic that becomes the hottest in times of economic recession. Indeed, with 8 million jobs lost since the Great Recession began and with painfully slow recovery (some economists believe that it may take up to five years to replace current job losses) (Sasseen 2009), the nation is anxious about further prospects of employment instability. According to a Bloomberg National Poll (Business Week 2009), $81 \%$ respondents see persistently high unemployment as the top threat to U.S. economic performance over the next two years (2010-2011). Their worries seem justified as it takes longer and longer for the U.S. economy to replace the jobs lost in each next recession (Sasseen 2009). So, do we observe significant changes in the structure of U.S. employment? The volume Laid Off, Laid Low helps to shed some light on the above question, as it revolves around recent trends in several aspects regarding job security.

This book is a collaborative effort of several authors and is carved into five chapters, each of which can be read independently. Chapters 1 and 2 focus on the instances of long-term employment and conclude, with some caveats, that the U.S. economy tends to become somewhat less oriented towards this once important feature of its labor market. The analysis presented by Henry Farber (Chapter 1) points to significant differences between private and public sectors when it comes to the opportunities for life-time employment. For males, the average tenure and the likelihood of long-term employment in the private sector have been steadily declining since the 70s. The opposite, however, can be observed in the public sector where the incidence of long-term employment has increased over the same time period. In contrast, there were no significant changes in long-term employment among women in the private sector, and even more substantial (comparing to men) increase in the prevalence of long-term employment in the public sector. These findings, however, should be understood in the context of dramatic increase in the female labor force participation over the past haft century. Such increased female attachment to the labor force could, in fact, offset the decline in long-term employment opportunities in the private sector. Given that the structure of the private sector is evolving towards less incidence of long-term employment, the public sector

I. Shevchuk ( $\square)$

Katz Graduate School of Business, University of California, Riverside, PA 15260, USA

e-mail: iryna.shevchuk@live.com 
becomes more attractive in terms of job security as the pattern of its employment relationships appears to be more stable and less susceptible to economic cycles. At the same time, the public sector comprises around one fifth of the overall employment in the United States and is unlikely to increase its share significantly in the future. So, in the scale of the overall economy the prevalence of life-time employment is decreasing.

While Henry Farber (Chapter 1) has analyzed careers of both men and women of different ages, i.e. from 20 to 65, Ann Huff Stevens (Chapter 2) has adopted a retrospective approach and limited her sample only to several cohorts of males who already retired and terminated their participation in the labor force. She makes an important methodological observation and suggests that conclusions about the trends in the length of workers' longest jobs depend on the endpoints over which these trends are calculated. So, one can observe a decline of two to four years in the average tenure on the longest job when analyzing trends starting in 1975 or 1980 . However, little changes are seen over the larger period from 1969 to 2004. Apart from the importance of this observation from the methodological perspective, it offers an interesting speculation: as the distribution of unemployment risks is consistent with economic cycles, so the incidences of long-term employment may be features of generations, i.e. some are just more blessed than others to enjoy higher job security.

Chapter 3, in turn, examines two other related elements of job insecurity - risk of unemployment and chances of reemployment. In a nutshell, Benjamin J. Keys and Sheldon Danziger confirm the existing knowledge that the more educated enjoy better job stability, younger workers are more likely to loose their jobs but have higher chances of reemployment, and minorities are more disadvantaged in terms of job security, but this effect is partially due to the differences in educational attainment.

While education indeed seems to provide a quite reliable insulation from economic downturns and the educated Americans have always enjoyed far more economic security than their less-educated peers, the analysis of perceptions about job insecurity, presented by Elisabeth Jacobs and Katherine S. Newman in Chapter 4, reveals a worrying pattern. Gloomy predictions about the financial and job security are, not surprisingly, dominant among the least fortunate ones, i.e. low-educated and low-income individuals. However, the recent trends signal that those socio-economic groups who were perceived as quite secure from economic bumps - college graduates and white-collar workers -now feel less job security than before. The objective conditions in the labor market suggest that there are enough reasons behind the above concern. Although, the overall employment rate for college graduates is not sensitive to economic cycles and remains pretty flat and low (around 2\%, as suggested in Chapter 3 ), the consequences of job losses have changed dramatically since 1980s. While those college graduates and managerial employees who lost their jobs still have good chances to find alternative employment, they are most likely to face a tangible drop in income (around 23\% of earning losses comparing to those similar ones, who were luckier). Such a situation is even more pronounced for older workers, since they are likely to experience significant pay cuts together with difficulties in finding alternative employment.

These structural changes in the U.S. employment market occur in the context of dramatic increase in income inequality, which now has reached its maximum since 1920s. Such an increase in income inequality does not remain unnoticed or tolerable among everyday Americans. More and more respondents express their concerns with income and wage inequalities. The authors conclude that "Americans' tolerance for 
inequality may not have changed, but that the level of inequality the country has experienced over the last several decades has exceeded what Americans are willing to accept" (p.91). The rising support for public safety net programs seems to be a natural consequence of the increasing levels of frustration with economic inequality.

Chapter 4 discusses perceptions of economic insecurity. Philipp Rehm (Chapter 5) demonstrates that Americans, on average, are quite realistic in their estimation of chances to lose their jobs. There is a strong association between individual perceptions of job insecurity (e.g. "I will likely lose my job next year") and the actual risks of unemployment measured as occupation-specific unemployment rates. The main point of this chapter, however, is the claim that nowadays an individual's occupation becomes a strong predictor of a person's partisanship (party affiliation, vote choice) even after controlling for such established variables as education, gender, age, church attendance, etc. The logic behind this claim is quite compelling. Indeed, in most cases an individual's occupation has a meaningful effect on a person's income and unemployment risk exposure. In turn, people with low income and high risks of unemployment tend to favor redistribution policies, since they are quite likely to need them in the future. The opposite is true for those with high income and low risks of unemployment. In terms of political preferences, those in favor of redistribution policies tend to associate themselves with Democrats, while those less supportive of redistribution tend to associate themselves with Republicans. Thus occupation, with its impact on current (income) and future (chances of employment) financial situation, has a considerable effect on political choices.

An interesting twist comes from a finding that today, unlike forty years ago for example, income levels and unemployment risks associated with a certain occupation has become tightly associated. Risk polarization together with increased income inequality implies that the poor are becoming not only poorer but also more exposed to unemployment risks, while the rich are becoming not only richer but also enjoy greater economic security. In a situation with such a clear segmentation of electorate, Democrats have an obvious advantage when raising the economic issues in the political debate. The 2008 elections that happened in the midst of economic turmoil seem to stay in line with theorizing presented by Phillip Rehm in Chapter 5.

Overall, this is a good read for those interested in the current trends regarding several aspects of job security in the United States, including prevalence of long-term employment, unemployment risks across socio-economic strata, and perceptions of job security. While the volume has kept its promise and contains a decent discussion of political consequences resulting from modern trends in labor market, there is, however, little offered about economic consequences despite suggested by the title Laid Off, Laid Low: Political and Economic Consequences of Employment Insecurity.

Open Access This article is distributed under the terms of the Creative Commons Attribution Noncommercial License which permits any noncommercial use, distribution, and reproduction in any medium, provided the original author(s) and source are credited.

\section{References}

Business Week (2009) America the Skeptical. December 21: 22

Sasseen, J (2009) The slow road to jobs. Business Week, December 7: 20-22 